\title{
Android-Base m-Voting Application Development With Simple Additive Weighting Method
}

\author{
Devi Sartika ${ }^{1, *}$ Leni Novianti ${ }^{1}$ Dewi Irmawati ${ }^{1}$ Ienda Meiriska ${ }^{1}$ \\ ${ }^{1}$ Study Program of Informatics Management, State Polytechnic of Sriwijaya \\ ${ }^{*}$ Corresponding author. Email: leni_novianti_mi@polsri.ac.id
}

\begin{abstract}
This research arranged to build a m-voting android-based application and started the registration by input student's data. The students can use m-voting as a tool to vote one of the student governor candidates on the election executive governor based on their conscience in the campus. The vote count will be processed by simple additive weighting (SAW). Its criterias are vision, mission, leadership skill, experience, and attitude. The output will show the result from the voting process who is the student governor that has been chosen and the total of voters who have already accessed. Researchers using PIECES development system method to ensure the system has a good performance.
\end{abstract}

Keywords: M-Voting, Simple Additive Weighting (SAW), PIECES

\section{INTRODUCTION}

Voting is the important activity to determine the result in every election event. There are concerns that should be accomodated, particularly for how the election must be held, how the regulation or rules that have been negotiated, and how to specify who is elected and who is entitled to vote. State Polytechnic of Sriwijaya using voting by conventional method to determine Student's Governor and Deputy Governor. Its method has such a procedure to hold the election. First, all of the students accept the formulir that contains the candidate's name. Then, all of the students will choose one of the candidates by number's candidates. After that, the formulir will be collected in the TPU box as a formulir storage. The committee will open the box and start to have counting from each candidate. Each TPU from each major/class will be counted to be the total vote result. By using a conventional voting system, it will take a long time to get the vote results and also the time that should be used for the learning process is used for the voting process. This voting process can be done without interrupting the study time, it means the students can vote after the learning has been done or after students return home.

Android is an operating system that is open source and has various advantages and has various advantages including the many built-ins that have been included, such as GPS services, high graphics quality and has portability in various current and future hardware and multitasking.. The android application on the google
Android App Market makes android able to match other OS. Therefore, android-based m-Voting Case Studies at the Department of Informatics Management at the Sriwijaya State Polytechnic to build an android-based mVoting Application so it can be applied and useful for Sriwijaya State Polytechnic and other universities that need accurate information in making decisions so it can support efficiency and work effectiveness of higher education institutions in general and Sriwijaya State Polytechnic in particular.

\section{DESCRIPTION OF STUDY AREA}

So far, Sriwijaya State Polytechnic has used the conventional voting method to determine the Student Governor and Student Deputy Governor by giving all students in each class a sheet containing the names of the candidates nominated as candidates for Student Governor and Student Deputy Governor, then the student will choose one of these candidates. After students make their choice, the ballot sheets will be collected in a box placed in front of the TPU. The committee opens the box and then calculates the results of each candidate. After all the classes have finished making their votes, all the votes from all the classes will be added up to calculate the total votes.

Uses smartphone technology based android, it is expected that it can provide information to the student governor candidates they will choose. And without interrupting learning class. Because smartphones are no 
longer luxury items right now but have become gadgets that all students have. The current problems are:

1. There is no online voting application for the student governor election process.

2. Inadequate use of technology to improve information services to students in conducting the election for the candidate of Student Governor, especially in the department of Informatics Management.

Then, to optimize the election for the candidate of Student Governor in the Department of Informatics Management, how to design, build and develop an Android-based m-Voting application for the election of a Student Governor in the Department of Informatics Management.

\subsection{Smartphone}

According to the Oxford Dictionaries www.oxforddictionaries.com smartphone is "A mobile phone that is able to perform many of the functions of a computer, typically having a relatively large screen and an operating system capable of running general-purpose applications."

Meanwhile, according to the Business Dictionary (www.businessdictionary.com), smartphones are "Mobile phones which include functions similar to those found on personal computers. Smartphones provide a one-stop solution for information management, mobile calls, email sending, and Internet access. Smartphones are compact in size and often only slightly bigger than standard mobile telephones.

\subsection{SIMPLE ADDITIVE WEIGHTING (SAW)}

\subsubsection{Simple Additive Weighting Method (SAW)}

According to Latif (2018:21) in (Delia, 2019:28), SAW is a simple weighting method or weighted addition to problem adjustments in a decision support system. The concept of this method is to find a performance rating (priority scale) on each alternative in all attributes.

\subsubsection{Analysis Function Model SAW}

The formula used in the Simple Additive Weighting method, namely: Normalizes each alternating (calculates the performance rating value)

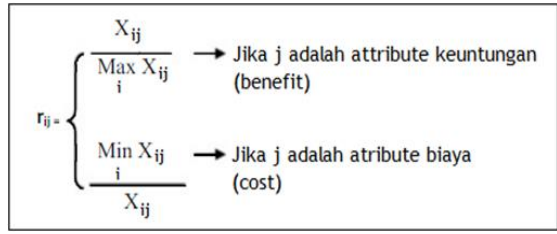

Calculate the preference weight value for each alternative

$$
V_{i}=\sum_{j=1}^{n} W_{j} r_{i j}
$$

Explanation:

Vi = Preference Weight Value of each alternative

wj = Criteria Weight Value

rij = Performance Rating Value

\section{RESEARCH METHODOLOGY}

\subsection{Problem Formulation Stage}

This step is the process of formulating the problem and restricting the problem to be researched. This is needed in order to direct researchers in building applications so what is done is not outside the restrictions.

\subsection{Data Collection Stage}

In the data collection step, the author refers to the opinion of Suryabrata (39: 2015), where this opinion explains the data collection method which divides the method into two types, namely:

1. Primary data is data that is first recorded and collected in a research. Primary data (main data) requires direct interaction with students.

2. Secondary data is data collected from existing sources Here, the authors collect data indirectly by searching and studying references to journals, books, articles, supporting theories and other references related to research

\subsection{System Design Stage}

The system design used in this research is UML (Unified Modeling Language) which consists of Use Cases, Class Diagrams, Activity Diagrams, and Sequence Diagrams.

\section{RESULT AND DISCUSSION}

\subsection{Algorithm Calculation Simple Additive Weighting (SAW)}

Calculation Simulation of Simple Additive Weighting

1. Determine the criteria for decision making. 
Table 1. Decision Making Criteria.

\begin{tabular}{|c|c|c|}
\hline $\begin{array}{c}\text { Crit } \\
\text { eria }\end{array}$ & Explanation & Weight $(\mathbf{W})$ \\
\hline C1 & Vision and mission & $0.25(25 \%)$ \\
\hline C2 & Leadership & $0.25(25 \%)$ \\
\hline C3 & Experience & $0.25(25 \%)$ \\
\hline C4 & Behavior & $0.25(25 \%)$ \\
\hline
\end{tabular}

2. Provide value and weight for each alternative on each predetermined criteria

Table 2. Value and Criterion Weights

\begin{tabular}{c|c}
\hline Variable & Weight $(\mathbf{W})$ \\
\hline Bad & 0.25 \\
\hline Enough & 0.5 \\
\hline Good & 0.75 \\
\hline Very Good & 1 \\
\hline
\end{tabular}

3. List of alternative

Table 3. List of Prospective Student Governor Candidates

\begin{tabular}{|c|c|c|c|c|}
\hline \multirow{2}{*}{$\begin{array}{c}\text { Data of } \\
\text { Prospective } \\
\text { Candidate }\end{array}$} & \multicolumn{4}{|c|}{ Criteria } \\
\hline & C1 & $\mathrm{C} 2$ & C3 & C4 \\
\hline $\begin{array}{c}\text { Friski } \\
\text { Kasviko }\end{array}$ & 3 & 2 & 4 & 4 \\
\hline $\begin{array}{l}\text { Aditya } \\
\text { Kesuma }\end{array}$ & 3 & 3 & 3 & 4 \\
\hline Jaya & 2 & 3 & 3 & 2 \\
\hline Riki & 3 & 1 & 4 & 2 \\
\hline
\end{tabular}

4. Determine the suitability rating of each alternative on each criteria

\begin{tabular}{c|c|c|c|c}
\hline \multirow{2}{*}{$\begin{array}{c}\text { Data of } \\
\text { Prospective } \\
\text { Candidate }\end{array}$} & \multicolumn{4}{|c}{ Criteria } \\
\cline { 2 - 5 } & $\mathbf{C 1}$ & $\mathbf{C 2}$ & $\mathbf{C 3}$ & $\mathbf{C 4}$ \\
\hline Friski Kasviko & 0.75 & 0.5 & 1 & 1 \\
\hline $\begin{array}{c}\text { Aditya } \\
\text { Kesuma }\end{array}$ & 0.75 & 0.75 & 0.75 & 1 \\
\hline Jaya & 0.5 & 0.75 & 0.75 & 0.5 \\
\hline Riki & 0.75 & 0.25 & 1 & 0.5 \\
\hline
\end{tabular}

Table 4. Determining the Rating

5. Make a decision matrix for each criteria. The decision matrix $(\mathrm{X})$ is formed from the suitability rating table of each criteria. The value from the results of the compatibility table is then made into a matrix form as follows:

$\mathrm{X}=\left(\begin{array}{lllll}0.75 & 0.51 & 1 & 0.750 .750 .7510 .50 .750 .750 .5\end{array}\right.$ $0.750 .2510 .5)$

(0.75 0.5110 .750 .750 .7510 .50 .750 .750 .50 .750 .2510 .5

6. Creating a Normalized Matrix

$\mathrm{R}_{11}=\frac{0.75}{\max \{0.75 ; 0.75 ; 0.5 ; 0.75\}}=1$

$\mathrm{R}_{12}=\frac{0.5}{\max \{0.5 ; 0.75 ; 0.75 ; 0.25\}}=0,6667$

$\mathrm{R}_{13}=\frac{1}{\max \{1 ; 0.75 ; 0.75 ; 1\}}=1$

$\mathrm{R}_{14}=\frac{1}{\max \{1 ; 1 ; 0.5 ; 0.5\}}=1$

$\mathrm{R}_{21}=\frac{0.75}{\max \{0.75 ; 0.75 ; 0.5 ; 0.75\}}=1$

$\mathrm{R}_{22}=\frac{0.75}{\max \{0.5 ; 0.75 ; 0.75 ; 0.25)}=1$ 


$$
\begin{aligned}
& \mathrm{R}_{23}=\frac{0.75}{\max \{1 ; 0.75 ; 0.75 ; 1\}}=0.75 \\
& \mathrm{R}_{24}=\frac{1}{\max [1 ; 1 ; 0.5 ; 0.5)}=1 \\
& \mathrm{R}_{31}=\frac{0.5}{\max \{0.75 ; 0.75 ; 0.5 ; 0.75\}}=0,6667 \\
& \mathrm{R}_{32}=\frac{0.75}{\max \{0.5 ; 0.75 ; 0.75 ; 0.25\}}=1 \\
& \mathrm{R}_{33}=\frac{0.75}{\max \{1 ; 0.75 ; 0.75 ; 1\}}=0.75 \\
& \mathrm{R}_{34}=\frac{0.5}{\max [1 ; 1 ; 0.5 ; 0.5]}=0.5 \\
& \mathrm{R}_{41}=\frac{0.75}{\max \{0.75 ; 0.75 ; 0.5 ; 0.75\}}=1 \\
& \mathrm{R}_{42}=\frac{0.25}{\max \{0.5 ; 0.75 ; 0.75 ; 0.25\}}=0,3333 \\
& \mathrm{R}_{43}=\frac{1}{\max [1 ; 0.75 ; 0.75 ; 1]}=1 \\
& \mathrm{R}_{44}=\frac{0.5}{\max \{1 ; 1 ; 0.5 ; 0.5\}}=0.5
\end{aligned}
$$

The matrix normalization process is based on equations adjusted for the type of attribute so that the normalization matrix $\mathrm{R}$ is obtained as follows:

$\mathrm{R}=\left(\begin{array}{lllllll}1 & 0.66671 & 1 & 1 & 0.7510 .666710 .75 & 0.51\end{array}\right.$ 0.333310 .5 ) ( 10.666711110 .7510 .666710 .750 .510 .33331

7. Finds the resulting value for the ranking of each prospective. Determining the values V1 to V4 is as follows:

$$
\begin{aligned}
\mathrm{V} 1 & =(0,25 \times 1)+(0,25 \times 0,6667)+(0,25 \times 1) \\
& +(0,25 \times 1) \\
& =0,25+0,166675+0,25+0,25
\end{aligned}
$$

$$
\begin{aligned}
& =0,916675 \\
\mathrm{~V} 2 \quad & (0,25 \times 1)+(0,25 \times 1)+(0,25 \times 0,75)+ \\
& (0,25 \times 1) \\
& =0,25+0,25+0,1875+0,25 \\
& =0,9375 \\
\mathrm{~V} 3 \quad & (0,25 \times 0,6667)+(0,25 \times 1)+(0,25 \times 0,75) \\
+ & (0,25 \times 0,5) \\
= & 0,166675+0,25+0,1875+0,125 \\
= & 0,729175 \\
= & (0,25 \times 1)+(0,25 \times 0,3333)+(0,25 \times 1)+ \\
\text { V4 } & (0,25 \times 0,5) \\
= & 0,25+0,083325+0,25+0,12 \\
= & 0,708325
\end{aligned}
$$

So from the calculation results obtained the largest ranks, namely V2, V1, V3, and V4.

\subsection{System Design}

\subsubsection{Use Case Diagram}

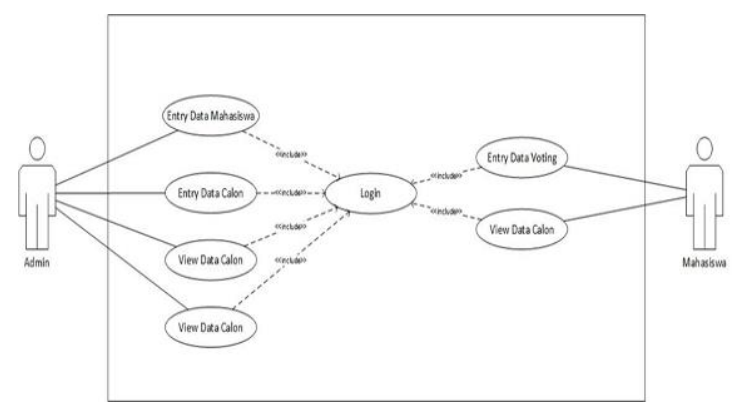

Figure 1. Use Case Diagram

\subsubsection{Class Diagram}

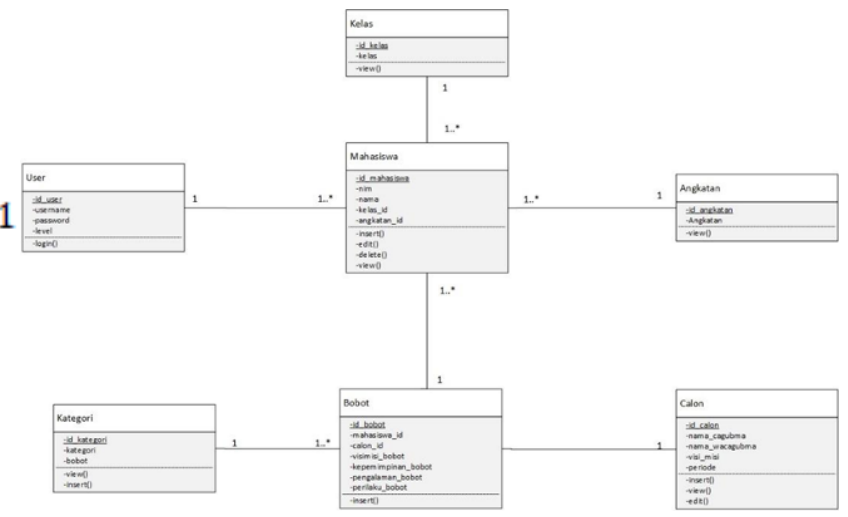

Figure 2. Class Diagram 
4.1.3 Activity Entry Data of Prospective

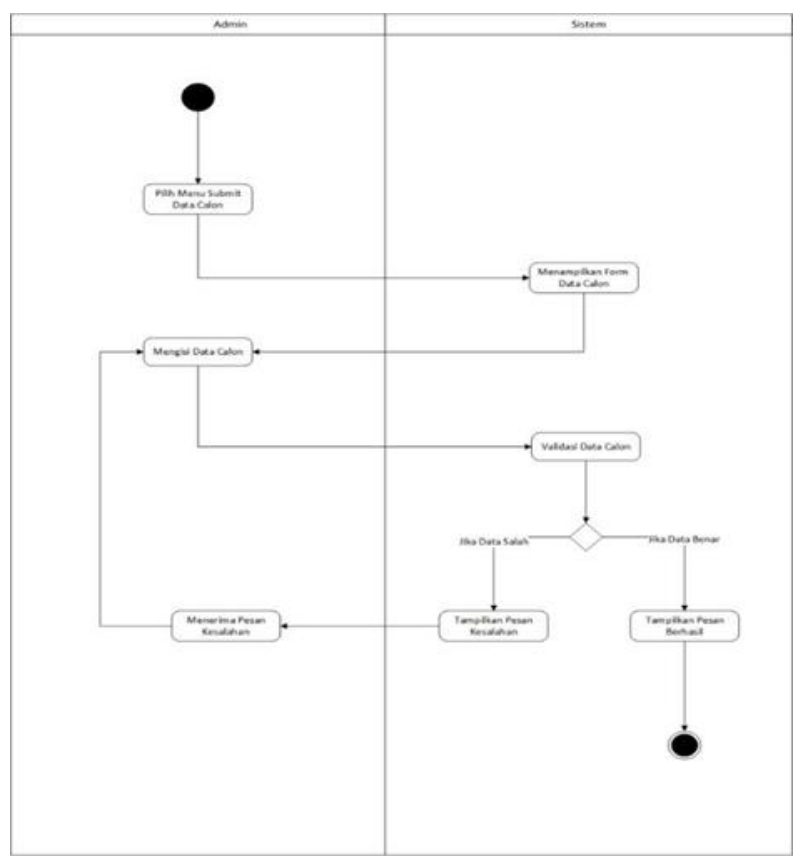

Figure 3. Activity Entry Data of Prospective

\subsubsection{Activity Entry Data of Student}

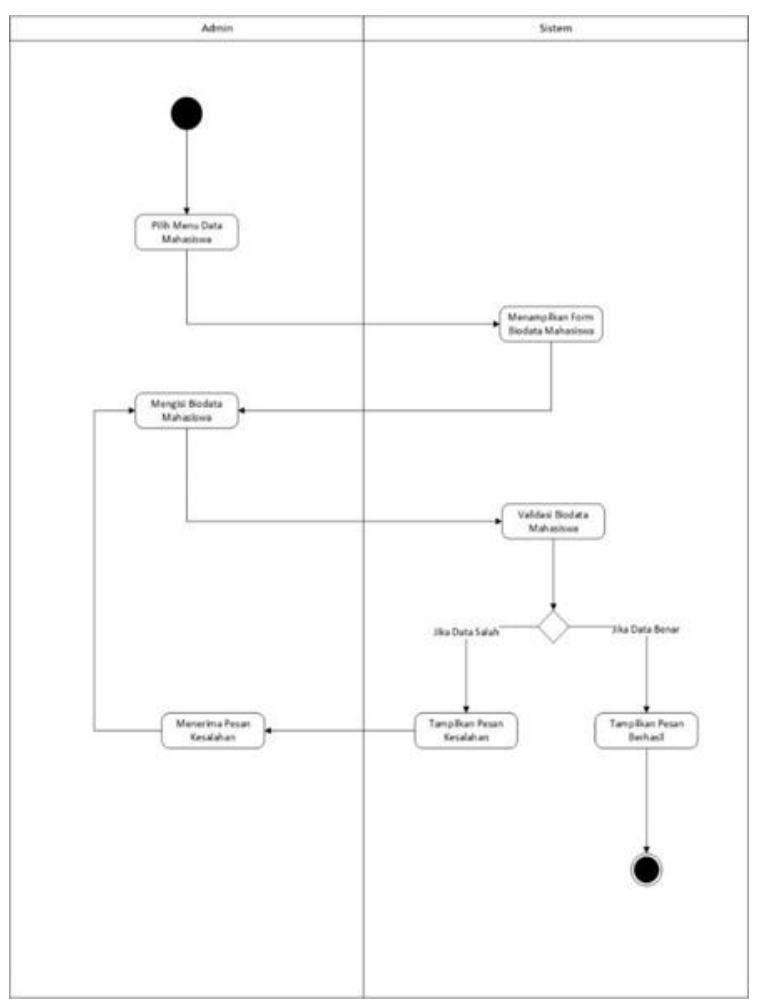

Figure 4. Activity Entry Data of Student

\subsubsection{Activity Entry Data of Voting}

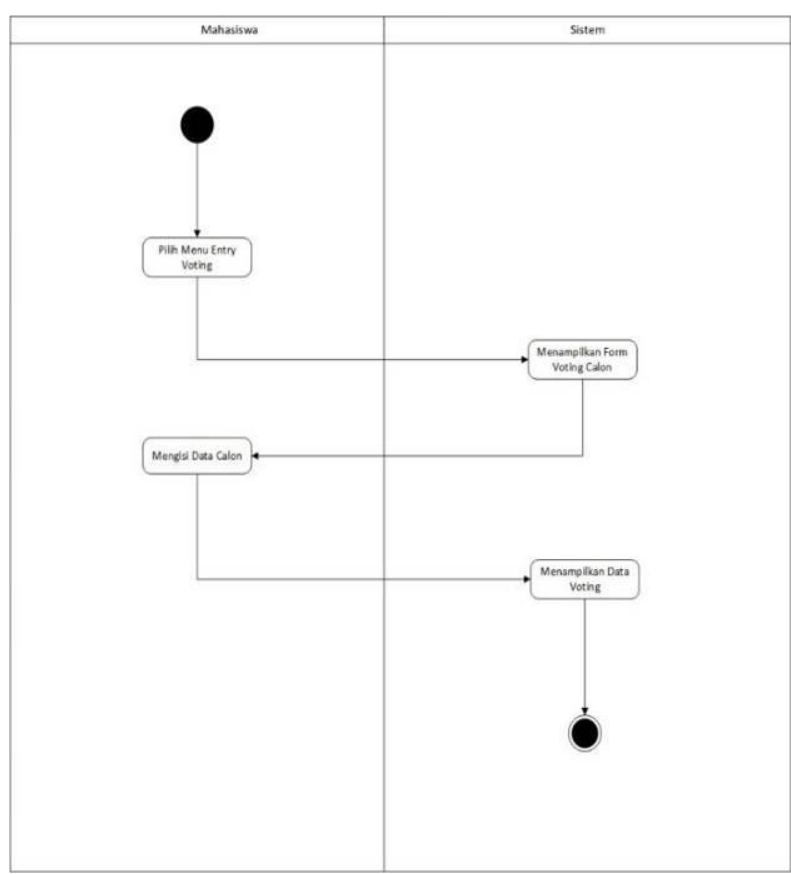

Figure 5. Activity Entry Data of Voting

\subsubsection{Activity Login Admin}

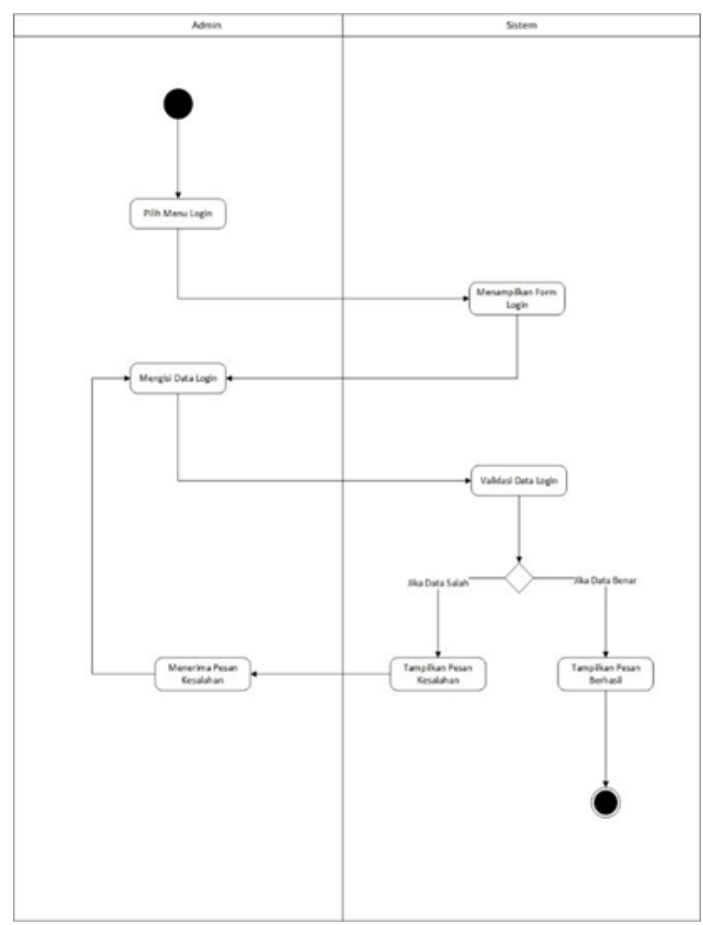

Figure 6. Activity Login Admin 


\subsubsection{Activity Login Student}

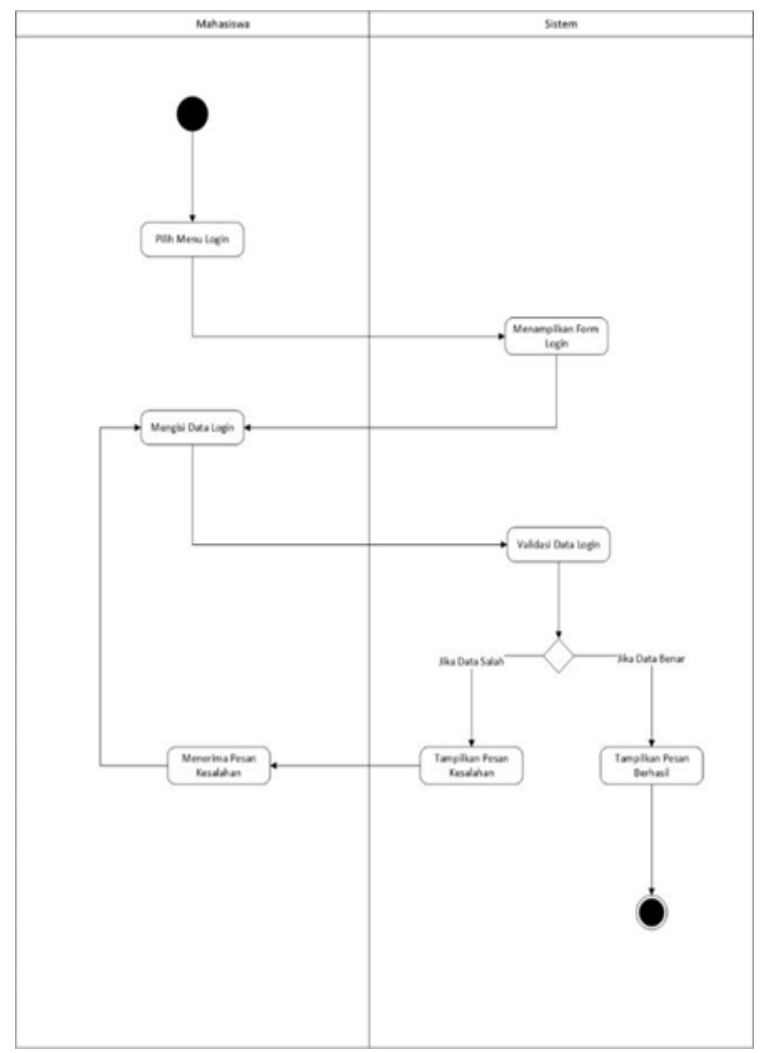

Figure 7. Activity Login Student

4.1.8 Activity View Data of Prospective Admin

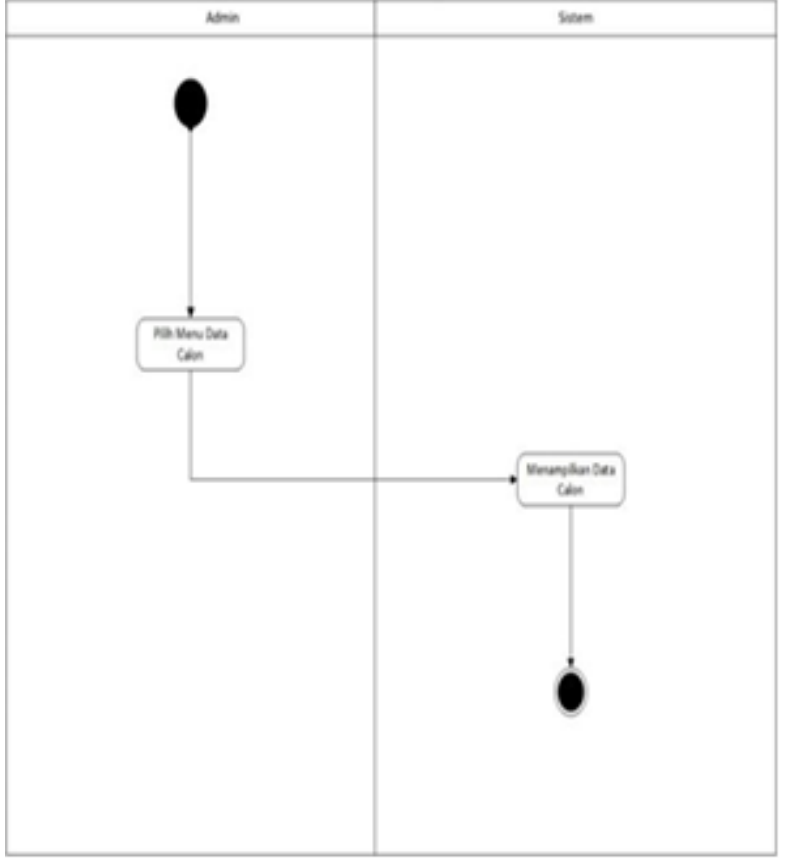

Figure 8. Activity View Data of Prospective Admin

\subsubsection{Activity View Data of Prospective Student}

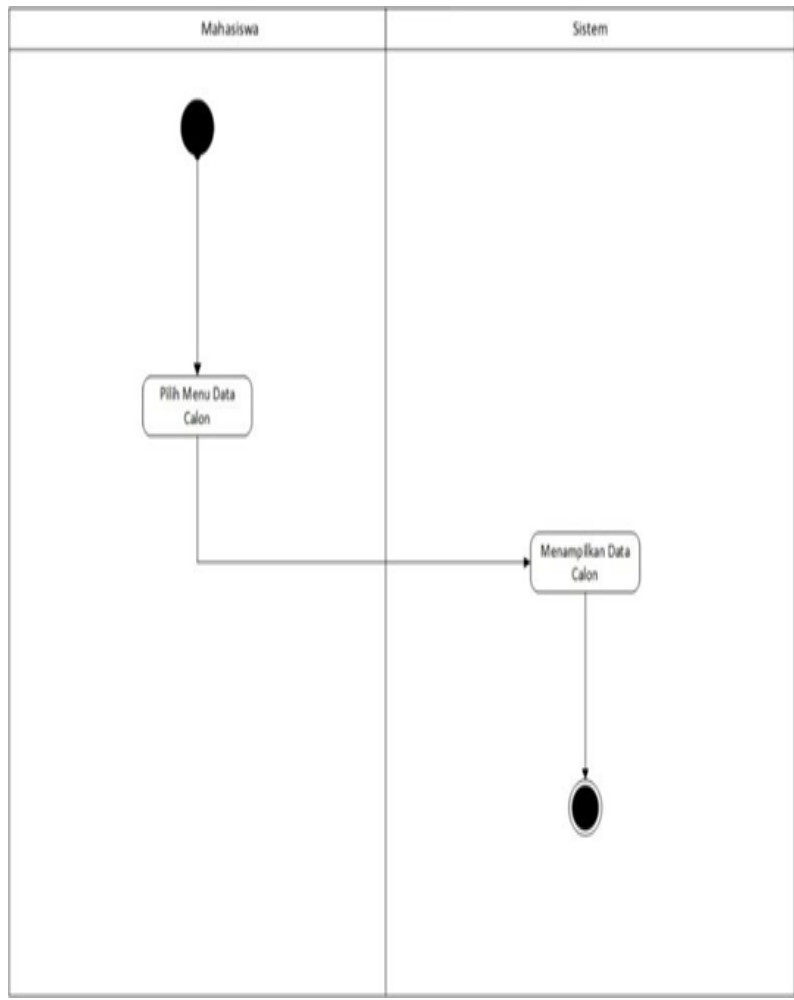

Figure 9. Activity View Data of Prospective Student 


\subsubsection{Activity View Data of Student}

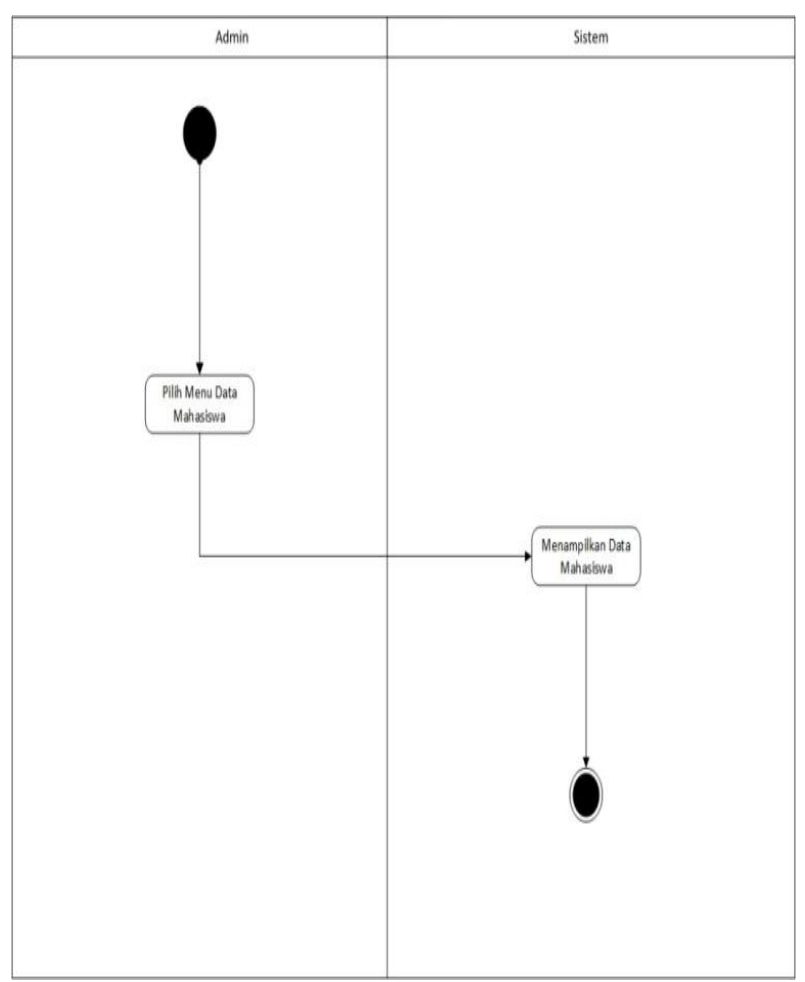

Figure 10. Activity View Data of Student

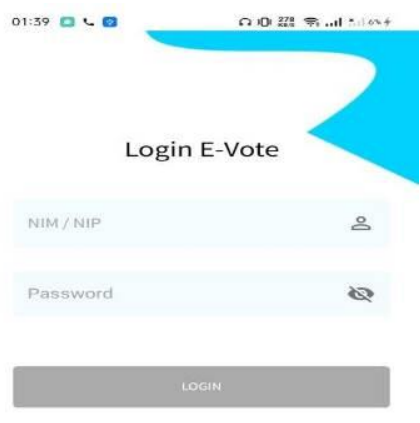

Figure 11. Login Page

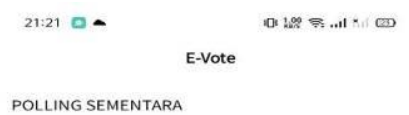

POLLING SEMENTARA

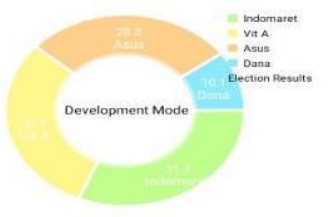

(2) Bakat Calon

圆 Data Mahasiswa >

2

Ubah Password >

E Logout

Figure 12. Admin Dashboard

21:220

$10,200=\ldots 1 \times 10$
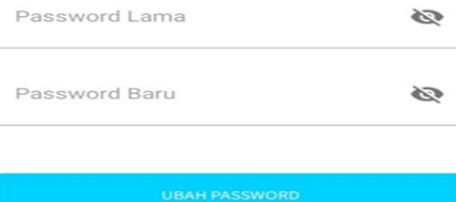

Figure 13. Change Password Menu
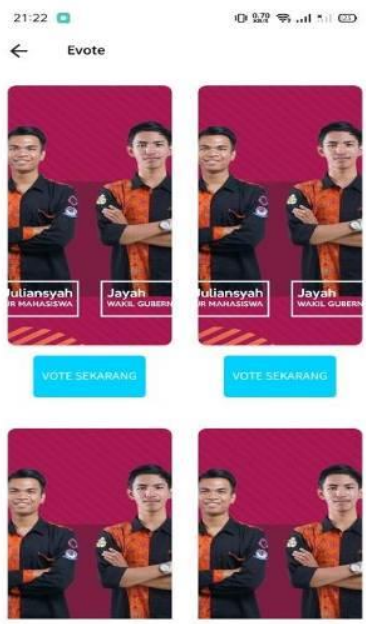
Figure 14. Prospective Student Governor Candidate Page

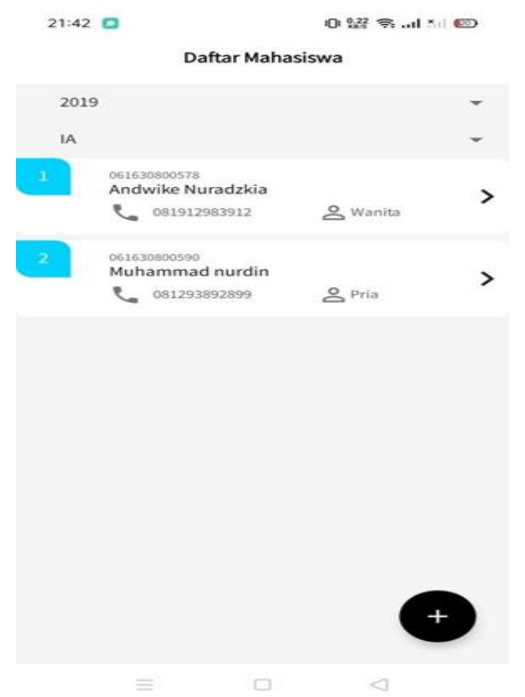

Figure 15. Voter Data Page (Student)

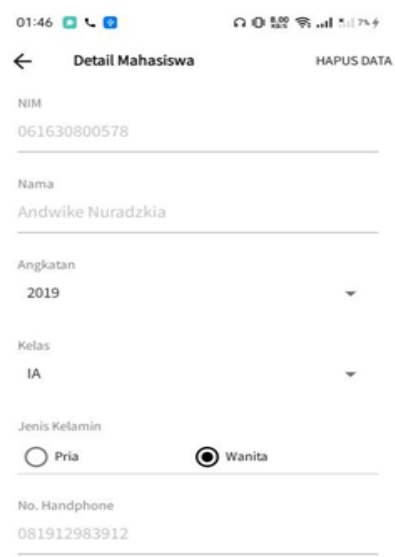

Figure 16. Voter Student Bio Page

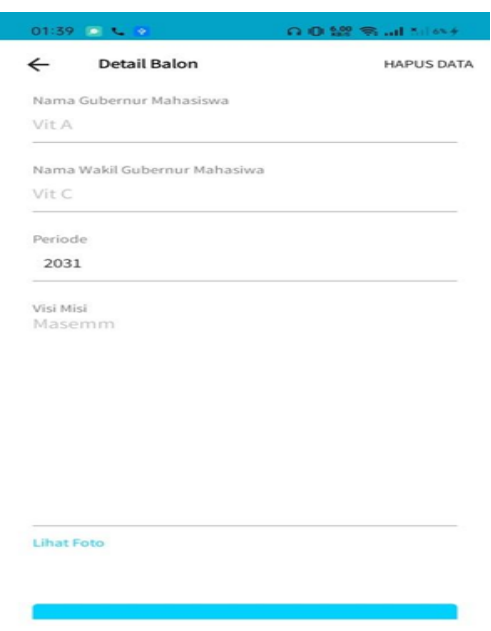

Figure 17. CV of Prospective Student Governor

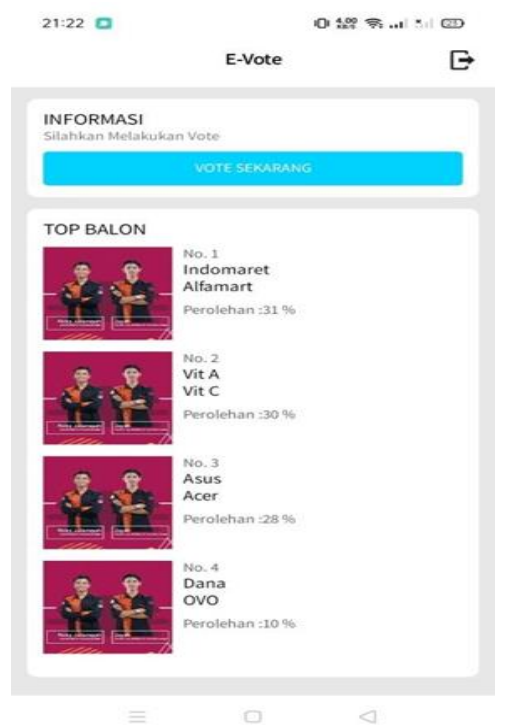

Figure 18. Dashboard Student

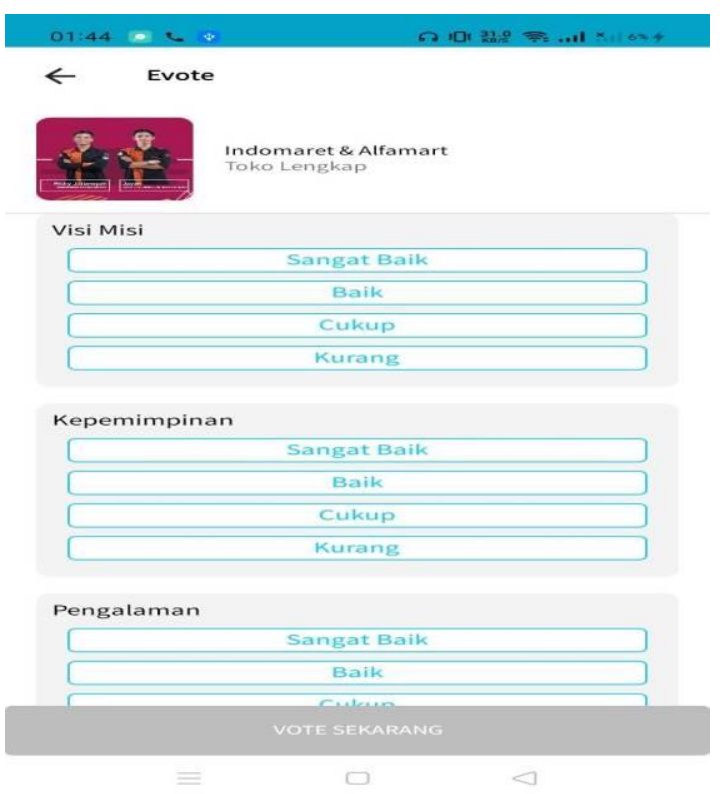

Figure 19. m-Voting Page

\section{CONCLUSIONS}

The results of the discussion can be concluded that:

1. The m-Voting application purpose is to provide information to voters to vote for prospective Governor Candidates for students majoring in Informatics Management.

2. The m-voting application consists of 9 menus, they are the login menu, admin dashboard, password change menu, the Candidates for Student Governor Candidates page, the voter data page, the voter student bio page, the biodata page of the prospective student governor candidates and the m-voting page.

3. This Android-based m-voting application was built using the Unified Modeling Language (UML). 


\section{REFERENCES}

[1] A. Gunawan, dkk. Aplikasi Mobile Voting Berbasis Android Untuk Pemilihan Ketua OSIS Dengan Model RAD Studi Kasus SMAN.1 Parungkuda. Jurnal Swabumi, Vol.6 No. September 2018. Pp. 139-142. P-ISSN : 2355 - 990X . E-ISSN : 25495178

[2] Huda, Arif Akbarul.2012. 24 Jam Pintar Pemrograman Android. Yogyakarta AndiOffset.

[3] Safaat H, Nazruddin. 2012. Android Pemrgraman Aplikasi Mobile Smartphon dan Tablet PC Berbasis Android. Bandung :Informatika.

[4] Supardi, Yuniar. 2011. Semua Bisa Menjadi Programmer Android. Jakarta : Elex Media Komputindo.

[5] R.Prananda, dkk. Rancang Bangun Aplikasi EVoting Berbasis Android (Studi Kasus: Pemilihan Ketua Organisasi Di Lingkungan Fakultas Teknik Universitas Tanjung Pura ). Jurnal Sistem dan Teknologi Informasi ( Justin). Vo.5 No.1 (2017).PISSN : 2460-3562, E -ISSN : 26208989.(jurnal.untan.ac.id/index.php/justin/arcticle/vi ew/1762)

[6] U.Qalsum, dkk. Mobile Voting Berbasis Flash Studi Kasus Pada Pemilihan Ketua OSIS SMAN. 10 Palembang .

(eprints.binadarma.ac.id/16.1/08142108_journal.pf)

[7] Y.Palopak . Implementasi Sistem E-Voting Berbasis Android Pada Sistem Pemilihan Langsung Di Lingkungan Universitas Advent Indonesia Menggunakan Framework Laravel. Jurnal Teknologi Informasi Dan Komunikasi. Vol.8 No.2 Oktober 2018. ISSN : 1979-6439. http://jurnal.unai.edu/index.php/teika/article/view/6 65.

[8]http://developer.android.com/studio/intro/index.html? $\mathrm{hl}=\mathrm{id}$ in accses 20 januari 2020 